Article

\title{
"I Didn't Have the Luxury to Wait": Understanding the University-to-Work Transition among Second-Generations in Britain
}

\author{
Jawiria Naseem \\ Department of Education and Social Justice, University of Birmingham, Birmingham, B15 2TT, UK; \\ E-Mail: j.naseem@bham.ac.uk
}

Submitted: 28 February 2019 | Accepted: 28 June 2019 | Published: 5 September 2019

\begin{abstract}
Second-generations - children of immigrants-experience particular university-to-work transitions in the UK, including precarious entry into the labour market This article examines the importance of intersecting social divisions, such as gender and ethnicity to these transitions, and also explores complexities within long-term economic progression. By comparing the educational achievement and labour market integration of British-born female graduates from one of the largestPakistani-and newly settled-Algerian-migrant groups and by focusing on long-term progression from the first job postgraduation to the most recent one. Using repeat semi-structured interviews with twelve British Pakistani and Algerian female graduates, this article produces a fine-grained analysis of key academic and economic stages. It reveals how the contextualised impact of intersecting social divisions-social class, ethnicity, as proxy for culture and religion, and genderand the ability to maximise and increase one's identity capital improve employability, transforming initial disadvantages into pathways for success.
\end{abstract}

\section{Keywords}

capital; ethnicity; female graduates; gender; second-generation; social class; UK labour market; university education

\section{Issue}

This article is part of the issue "Types of Education, Achievement and Labour Market Integration over the Life Course", edited by Irene Kriesi (Swiss Federal Institute for Vocational Education and Training, Switzerland) and Juerg Schweri (Swiss Federal Institute for Vocational Education and Training, Switzerland).

(C) 2019 by the author; licensee Cogitatio (Lisbon, Portugal). This article is licensed under a Creative Commons Attribution 4.0 International License (CC BY).

\section{Introduction}

Driven by colonial ties, Pakistani migrants arrived in the UK in the 1970s to support the country's industrial development following the end of World War II (Judt, 2007). Being predominantly male, uneducated and from working-class backgrounds, these migrants lacked immediate transferable skills, were confined to low-paid manual jobs and had limited opportunities to move up the social ladder (Rattansi, 2011).

Pakistani women, by contrast, arrived as spouses and experienced a more complex engagement in the labour market as upon migration, they suffered economically from the then declining industrial sector in the late 1970s (Brah, 1996, 2003). Being subjected to attributions that were in operation during colonial times (e.g., constraining cultures) created further obstacles as these affected the support the women received from governmental and educational bodies which in turn influenced jobs employers offered (Brah, 1996). Expectations from within their families to act as symbolic bearers of strict cultural, ethnic and gender identities also meant that these women were compelled to take on only unpaid jobs in family-run businesses or stay out of work (Afshar, 1989).

In many aspects, Algerians' settlement in the UK differs considerably from that of Pakistanis. For instance, Algerians do not have any colonial links with the UK which can have a significant impact on how they are perceived. Absence from the social imaginary of the majority ethnic group may indeed protect Algerians from the extent of negative stereotype experienced by Pakistanis, as a well-known group who has historically suffered from racism and discrimination (Rattansi, 2011; Weedon, 2004). Moreover, the initial wave of Algerian migrants 
in the 1980s included mostly well-qualified individuals (Collyer, 2003). It is only during the late $1990 \mathrm{~s}$ that migrants from more remote, poorer and rural areas, with limited education came to Britain and joined its industrial workforce (Collyer, 2003).

Unlike Pakistanis who are now the second largest South Asian group and the largest Muslim group in the UK (Office for National Statistics, 2016), there are only an estimated 22,000 Algerian migrants (Migration Policy Centre, 2013). It is mainly a male population, very young and for the most part with no academic qualifications (The Change Institute, 2009). However, Collyer (2003) has argued that university-educated but undocumented Algerians are unable to secure professional jobs as a result of their illegal status in the country. Similarly, he pointed to the limited opportunities for Algerian healthcare professionals to work as independent practitioners because of the language requirement necessary for the recognition of their qualifications.

Although structural barriers affect the employability of university-educated migrants, their UK-born children, the second-generation, can become a means of upward social mobility for the family by gaining academic qualifications (Modood, 2004). Indeed, in post-industrial European countries, such as the UK, significant value is attached to Higher Education (HE) qualifications which are perceived to guarantee individual economic success (Organisation for Economic Co-operation and Development $[O E C D], 2018)$. By opening access to high-skilled jobs with higher earnings, academic qualifications can thus help second-generation to transcend initial individual and family disadvantages over the life course, including class and/or ethnic disadvantages especially those experienced within the context of migration (OECD, 2018).

Using semi-structured interviews, this article focuses on the university-to-work transition among British-born Pakistani and Algerian female graduates. The relationship between educational achievements and labour market outcomes is examined through elements of stratification of HE, including choice of institution and field and level of study. This cross-group comparison offers a unique insight into how intersecting social divisionsgender, class and ethnicity-may influence educational and employment pathways not only in access to first job post-graduation but also in terms of long-term impact of $\mathrm{HE}$ qualifications on career progression.

\section{Theoretical Framework}

Bourdieu (1980) argues that children from working-class backgrounds are unlikely to succeed in tertiary education unless they undergo a process of acculturation, that is, they acquire a minimum of the social and cultural capitals which dominate in HE and are shared by their privileged peers. Consequently, they struggle at the lowest levels of society, educationally and professionally, as they lack profitable capital altogether-including material, social and cultural forms.
Although Bourdieu's point on acculturation is useful, it remains grounded within a class-based perspective, overlooking the importance of other intersecting social divisions such as ethnicity as argued by Modood (2004), for whom, children of immigrants do not have to acculturate to succeed in HE. By examining the 'unconventional' educational patterns of working-class minority ethnic students, he suggests that these students may lack profitable capital, as defined by Bourdieu, but possess an ethnic capital, that is their individual agency and parental involvement, which works to raise aspirations for the pursuit of, and success in, tertiary education.

Encompassing all forms of capital (i.e., material, social, cultural and ethnic), Côté (1996, p. 424) advances the concept of identity capital which examines how individuals develop educational, social and psychological resources "to secure social-class mobility, or to reproduce one's class position". In relation to education, this concept offers insights into how students negotiate their education-to-work transition; placed within the labour market framework, it recognises how individuals manage their entry and then maintain their professional positions. Identity capital thus allows understandings of how "social background, educational experiences, and other "investments'" can materialise into economic success over the life course (Côté, 1996, p. 424). The latter relates to investment in one's identities such as one's student identity (e.g., through completion of additional degrees).

In that sense, the existence of multiple identities, shaped along various categories, allows for the intersection of all forms of capital and in turn, understanding these multiple identities illuminates how individuals negotiate new social positions. This is precisely what Anthias (2008) argues but with a focus on the spatial and contextual processes involved in the construction of social positions, such as student and worker positions, making it possible to uncover how individuals are placed (or place themselves) in a given space at a certain time. Attention to contextualised social positions thus complements the fluid reading of Côté's $(1996,2002)$ notion of identity capital since it recognises shifts in how identity capital can be used as a resource, for example, for educational and employment achievements.

In this article the notion of identity capital helps to understand how individuals deploy strategies to navigate personal and structural challenges in a situated and relational way, not only during their university-to-work transition but also when settling within other social spaces such as $\mathrm{HE}$ and employment spaces. Additionally, the intersectional approach allows a consideration of social class, ethnicity-as a proxy for culture and religion-and gender dynamics. The latter relates to the ways in which the feminine body goes through pressure to conform to various expectations (Brah, 1996; Weedon, 2004). This intersectional framework helps to examine how the female participants in this study are positioned within their families and in society and how societal, cultural and religious expectations and/or barriers may operate to make 
them 'adjust' their behaviour, first, as students and then as professional women.

\section{Patterns and Gaps in UK Higher Education and Labour Market}

\subsection{Experiences and Outcomes of British Pakistani Female Graduates}

Although traditionally second-generation Pakistanis have had low educational attainment in compulsory and tertiary education, in recent years, these patterns have changed (Heath, Rothon, \& Kilpi, 2008). In 2017/18, eleven per cent of all university students were British Asians (Higher Education Statistics Agency [HESA], 2019). Compared to their White peers, they are now also more likely to go to university and pursue undergraduate studies (Modood \& Calhoun, 2015).

This increase in university participation is nonetheless shaped by intersecting factors involving structural barriers and personal social divisions including gender, ethnicity and social class. For instance, the existence of "institutional filtering", as Malik and Wykes (2018) suggest, partly explains the underrepresentation of minority ethnic students in elite universities. At the same time, working-class students tend to join local institutions to reduce financial costs, but also because of fears of not fitting in to more prestigious institutions (Reay, Crozier, \& Clayton, 2009). The latter is also true for minority ethnic students from middle-class backgrounds (Noden, Shiner, \& Modood, 2014). In that respect, for minority ethnic students, both social class and a sense of belonging, strongly influence university choices since these enable feelings of social acceptance at university by a group with whom they share similar characteristics (Bourdieu, 1980).

Research focused on South Asian women identifies an additional dynamic between gender and ethnic factors in producing university entry, experiences and outcomes (e.g., Dale, Shaheen, Kalra, \& Fieldhouse, 2002; Dwyer \& Shah, 2009; Hussain \& Bagguley, 2012). The need for South Asian women to maintain strict gender identities reinforces pressure to conform to cultural expectations, which in turn, affects their entry at university, especially for Pakistanis who may be subject to religious expectations too (Brah, 1996). They also have to negotiate the pursuit of tertiary education with their parents who view the university environment as a white space which can negatively impact on their daughters' behaviour (Ijaz \& Abbas, 2010). These negotiations may translate into applications made to local universities which would not require on-campus living for instance (Dwyer \& Shah, 2009).

These initial structural and personal barriers strongly impact British Pakistani graduates' transition into the labour market. For instance, qualifications from lessprestigious institutions restrict access to high-profile professions (Noden et al., 2014). Similar to their migrant peers, South Asian female graduates may also face racist and discriminatory practices and cultural stereotypes held by potential employers, preventing them from converting their qualifications into matched professional statuses (e.g., Kamenou, Netto, \& Fearfull, 2013; Khattab, 2009). These racist and discriminatory practices and cultural stereotypes are grounded in discourses of otherness which construct hierarchical positions between the 'us' (i.e., majority ethnic group) and 'them' (i.e., minority ethnic groups) in post-colonial societies (Rattansi, 2007). These discourses position the 'other' as constrained and subordinated and subsequently exclude it from (privileged) spaces, such as higher managerial and professional jobs, which are perceived to be an entitlement of the majority ethnic group (Goldberg, 2009).

Further research on the impact of ethno-religious factors on occupational attainment indicates that nonWhite British Muslim women with academic qualifications are less likely to "obtain high non-manual positions in the labour market" compared to their White Christian and Jewish counterparts (Khattab, 2009, p. 316). More specifically, Muslim Pakistani female graduates are less likely to be in full-time employment or to secure managerial and professional occupations than their Indian peers (Khattab, 2012). When compared to Pakistani men, these women face an "extra penalty" due to the existence of a gendered labour market (Khattab, 2009, p. 316) and gender-driven cultural expectations within their families (Dale et al., 2002). These findings suggest that British Pakistani women's transition and progression in the labour market are influenced by personal and structural factors since the existence of gender, religious and ethnic penalties positions these women behind their male counterparts, White women and Muslim Indian women.

\subsection{Experiences and Outcomes of British Algerian Female Graduates}

Existing research on Algerians has largely overlooked the position of the second-generation (Migration Policy Centre, 2013). A parallel with other minority ethnic groups, who are numerically less important than British Pakistanis and who have no shared colonial history with the UK, can provide insights into the group's education and work. For instance, research on British-born Chinese reveals that even though parental involvement in education leads to high attainment levels, the group experiences barriers in securing employment due to persisting initial disadvantages (Archer \& Francis, 2007). Moreover, research with Algerian parents highlights concerns about the upbringing of their children within an English environment, aspects of which are perceived to contradict their religious values (The Change Institute, 2009). Taken together, this evidence suggests that Algerian parents' involvement in their children's formal education may have two outcomes: (1) similar to Chinese parents, it may allow them to contribute to their children's academic success and (2) it may ensure that their children's behaviour 
is in line with religious expectations, mirroring Pakistani parents' involvement.

Upon entry and progression into the labour market, Algerian graduates may face difficulties due to their status as new graduate. For example, limited geographical mobility or lack of relevant work experience prior to graduation may limit job opportunities (Brown \& Hesketh, 2004). Moreover, persisting barriers as they affect Muslim and minority ethnic women in the labour market may also work to oppress and exclude female graduates, especially those who are visibly Muslim (e.g., Afshar, 2008; Malik \& Wykes, 2018). Nevertheless, being absent from the social imaginary of the majority ethnic group suggests the existence of a potential difference between the ways in which Pakistanis and Algerians are positioned and thus, Algerians may not be subjected to similar stereotypes as experienced by their Pakistani peers.

Despite being built on a parallel and research with migrant parents, the above evidence provides useful insights into the importance of gender, social class and ethnicity in the navigation of education and employment pathways among second-generation Algerians.

\subsection{Contributions to the Literature}

Although existing research offers useful understandings of British Pakistani women's education and employment outcomes, it, nevertheless, does so by grouping Pakistani women with other South Asian and Muslim women and focuses on education-to-work transition only or experiences/outcomes within education/employment. This article addresses these issues by examining qualitatively the dynamic between three important spheres, rarely brought together: family, education and the labour market. It does so (1) by separating Pakistanis from other South Asian and Muslim women, (2) by focusing on parent-daughter relationship and its impact on the daughters' education and employment, and (3) by providing insights into the graduates' career pathways over the life course.

Empirically, this article also depicts for the first time the educational and employment experiences of secondgeneration Algerians. By comparing Pakistanis, a wellestablished group, to Algerians, a newly settled one, it examines how two different minority ethnic groups engage in similar social, economic and structural settings. This furthers understandings of how specific life phenomena-education-to-work transition and progression once employed-impact both similarly and differently graduates from the two minority ethnic groups (Hantrais, 2009). This article thus considers similarities in class and gender positions in relation to differences in ethnic position and migration history.

\section{Data}

This article draws on a larger comparative study between France and the UK which brought together the largest
Muslim minority ethnic groups in each country, namely Algerian and Pakistani respectively. It specifically focuses on six British Pakistani and six British Algerian women recruited for the comparative study through snowballing and who participated in repeat in-depth semi-structured interviews between January 2012 and August 2013. The aim of the first interviews was to gather views on career ambitions, educational choices, university-to-work transition and long-term progression. Second interviews provided insights into potential socio-economic changes during the time of the research (e.g., return to education).

All participants were employed at the time of their recruitment. The youngest participant had 2 years of work experience post-graduation while the oldest had 22 years. This range allowed the examination and comparison of economic integration longitudinally, from the first job post-graduation to the professional position at the time of the first interview. Table 1 gives additional socioeconomic information.

\section{Discussion of Findings}

\subsection{Understanding University Pathways}

5.1.1. Post-92 or Elite University? Negotiating Choice of University and Strategies for Academic Success

Except two women who attended elite universities (Russell group institutions), all the other participants chose a less prestigious post-92 university, following the general pattern for minority ethnic students (e.g., Hussain \& Bagguley, 2012). The rationale for their choice was driven by gender and ethnic factors with the chosen institutions being local and/or ethnically diverse. For example, Neelum (Pakistani, working-class) attended a local post-92 institution because, as an unmarried woman, her family expected her to live at home (e.g., Dale et al., 2002). Similar gender and religious expectations also shaped her friends' circle:

My friends were mostly like me you know. Muslims. But not necessarily Pakistani. Like my best friend is Chinese but she is Muslim. I think it's good to have friends like you...because they go through the same thing.

The above extract also hints towards a lack of acculturation, as defined by Bourdieu (1980), since Neelum decided to make friends with other Muslims only which enabled her to create her own space and develop psychological and emotional resources (Côté, 2002). In that sense, religion was not only at the origin of family expectation, but it also became a resource to foster social support. Deploying religion as a resource was a strategy used by women in both elite and post-92 universities.

For example, Leila (Algerian, middle-class) attended a Russell group but local university, lived off-campus (for similar reasons to Neelum) and she too decided to form 
COGITATIO

Table 1. Key socio-economic characteristics of British Pakistani and Algerian participants.

\begin{tabular}{|c|c|c|c|c|c|c|c|c|}
\hline Pseudonym & Age & $\begin{array}{l}\text { Type of Local } \\
\text { University } \\
\text { Attended }\end{array}$ & Qualification & $\begin{array}{l}\text { First job post- } \\
\text { graduation }\end{array}$ & $\begin{array}{l}\text { Total years of } \\
\text { work experience } \\
\text { post-graduation }\end{array}$ & $\begin{array}{l}\text { Occupation during } \\
\text { first interview }\end{array}$ & Social class & Parental profession \\
\hline \multicolumn{9}{|l|}{ Pakistanis } \\
\hline Raheela & 28 & Post-92 & $\begin{array}{l}\text { Postgraduate diploma } \\
\text { in counselling }\end{array}$ & HR assistant & 6 years & $\begin{array}{l}\text { University programme } \\
\text { coordinator }\end{array}$ & Working-class & $\begin{array}{l}\text { F: Unemployed } \\
\text { M: Unemployed }\end{array}$ \\
\hline Neelum & 30 & Post-92 & PGCE in Physics & School assistant & 6 years & Physics teacher & Working-class & $\begin{array}{l}\text { F: Unemployed } \\
\text { M: Unemployed }\end{array}$ \\
\hline Mariam & 35 & Post-92 & $\begin{array}{l}\text { Postgraduate certificate } \\
\text { in English Literature }\end{array}$ & $\begin{array}{l}\text { TV Channel } \\
\text { programme assistant }\end{array}$ & 10 years & Care assessor & Middle-class & $\begin{array}{l}\text { F: Business owner } \\
\text { M: Head of secondary school }\end{array}$ \\
\hline Noreen & 35 & Elite & Master in Pharmacy & Surgical pharmacist & 10 years & Clinical lecturer & Middle-class & $\begin{array}{l}\text { F: Chemical engineer } \\
\text { M: Media analyst }\end{array}$ \\
\hline Sehrish & 42 & Post-92 & $\begin{array}{l}\text { Master in Media and } \\
\text { communication }\end{array}$ & Job centre advisor & 17 years & Executive director & Working-class & M: Unemployed \\
\hline Anya & 45 & Post-92 & $\begin{array}{l}\text { Master in Education } \\
\text { Management }\end{array}$ & $\begin{array}{l}\text { Restaurant } \\
\text { manager }\end{array}$ & 22 years & Deputy Head & Middle-class & $\begin{array}{l}\text { F: Restaurant owner } \\
\text { M: unemployed }\end{array}$ \\
\hline \multicolumn{9}{|l|}{ Algerians } \\
\hline Heena & 23 & Post-92 & $\begin{array}{l}\text { Bachelor in International } \\
\text { Business }\end{array}$ & Retail assistant & 2 year & $\begin{array}{l}\text { Special educational } \\
\text { needs advisor }\end{array}$ & Working-class & $\begin{array}{l}\text { F: Unemployed } \\
\text { M: Unemployed }\end{array}$ \\
\hline Latifa & 25 & Post-92 & Master in Marketing & Call centre operator & 3 years & $\begin{array}{l}\text { Junior Marketing } \\
\text { researcher }\end{array}$ & Working-class & M: Unemployed \\
\hline Saadia & 25 & Post-92 & Master in Journalism & Web content editor & 3 years & Freelance editor & Middle-class & $\begin{array}{l}\text { F: University lecturer } \\
\text { M: Unemployed }\end{array}$ \\
\hline Malika & 26 & Post-92 & Master in Psychology & Retail assistant & 2 years & $\begin{array}{l}\text { Assistant research } \\
\text { psychologist }\end{array}$ & Working-class & $\begin{array}{l}\text { F: Unemployed } \\
\text { M: Unemployed }\end{array}$ \\
\hline Leila & 26 & Elite & $\begin{array}{l}\text { Bachelor in Business } \\
\text { Management }\end{array}$ & Administrator & 4 years & Database analyst & Middle-class & $\begin{array}{l}\text { F: IT manager } \\
\text { M: Unemployed }\end{array}$ \\
\hline Karima & 30 & Post-92 & PGCE in Science & $\begin{array}{l}\text { Private Science } \\
\text { Tutor }\end{array}$ & 5 years & Science teacher & Working-class & $\begin{array}{l}\text { F: Unemployed } \\
\text { M: Unemployed }\end{array}$ \\
\hline
\end{tabular}

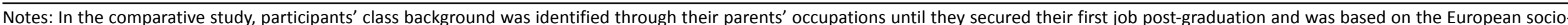

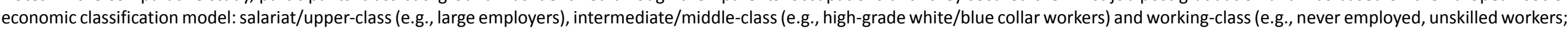

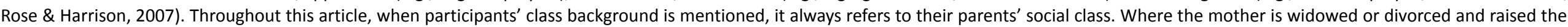
participant as a single parent, the father's profession has been disregarded. $\mathrm{F}$ stands for Father and $\mathrm{M}$ for Mother. 
a group membership with female and Muslim students only, thus avoiding the need to acculturate. In a way, by consciously excluding herself from the student life of the majority student cohort ("I didn't want to get involved [in Friday nights-out]"), Leila created an environment on the basis of exchangeable resources, to borrow Côté's (2002) term, such as appearance and values, leading to similar experiences of inclusion to the women in post-92 institutions. In that respect, women in prestigious and post92 institutions did not have to acculturate, as argued by Bourdieu (1980), but instead they drew on their existing identity capital strategically to build ethnically uniform social networks (grounded in religion) and in some cases, female only. This strategy constructed feelings of being accepted as a full member of a traditionally white space and thus, enabled the women to fit into the environment of $\mathrm{HE}$ as a Muslim female and minority ethnic student.

While choice of university was partly driven by the women's decision to meet their families' cultural, gender and religious expectations, other university-related decisions had to be in line with parental aspirations.

\subsubsection{Managing Parental Aspirations and Personal Preferences in Degree Subject and Level of Study}

The limit and extent of migrant parents' support in their children's education is well-documented. For instance, despite their positive intentions, they struggle to make a concrete difference to their children's actual attainment (e.g., Engzell, 2018). Yet, their material and emotional support works to raise their children's aspirations, leading to the successful pursuit of tertiary education (e.g., Jackson, Jonsson, \& Rudolphi, 2012; Lessard-Philips \& Li, 2017). Although the achievement of the Pakistani and Algerian participants mirrors these findings (i.e., they completed tertiary education thanks to parental motivation), many interviewees perceived going to university as a burden, forced upon them by their parents, producing similar experiences across groups regardless of ethnic and class differences:

If it wasn't for my parents I would have (pause) finished college and started working. But I did go to uni thanks to them. (Heena, Algerian, working-class)

I was in the mindset of doing some work, getting into the employment market [after A-levels]. My mum was like 'you got to do a Master' [sad voice]. My mum...she made me go to uni. She forced me [high pitch]. (Mariam, Pakistani, middle-class)

Both Heena and Mariam went to university unwillingly. In retrospect, Heena appreciates her parents' persistence in getting her to study for a degree, notably to gain financial independence (note the "thanks to them"). Financial independence was important to all parents (as reported by the women) which highlights a different class and gender intersection compared to existing research.
Indeed, previous findings suggest that encouragement to gain university qualifications are given to male secondgenerations, so they can support their families as breadwinners (e.g., Dale et al., 2002).

Unlike Heena, Mariam still recalls her experience as negative (note the "made me"/"forced"). Reportedly, the only route which would satisfy her mother was getting a masters; an undergraduate qualification was not enough. She resisted this pressure by completing one semester only which translated into a postgraduate certificate and led to her mother's disappointment. Heena and Mariam's pursuit of undergraduate and postgraduate qualifications respectively brings forth the importance of social class in influencing education-related decisions contextually. Loury, Modood and Teles (2005) argue that for minority ethnic groups from lower class backgrounds, higher educational achievements convey a sense of accomplishment, as they potentially open doors to social mobility. Heena's experience is a case in point since her achievement became a source of family pride ("[my father] was just...proud"). In Mariam's case, her mother's involvement ensured a reproduction of their family's social status since the importance was for Mariam to maintain prestige within her family's social network (Côté, 1996). In that sense, although social class differences were irrelevant in decisions regarding $\mathrm{HE}$ entry, these became prominent in explaining the rationale for the level attained.

While some women went to university unwillingly, others, who already intended to pursue tertiary education, experienced parental involvement as a barrier when they had to negotiate between their preferred degrees and what their parents considered as prestigious and/or lucrative degrees. For instance, Anya (Pakistani, middle-class) completed an Economics degree despite being interested in becoming an English teacher:

So obviously [the best thing for Pakistani parents] is the field of doctor and the next thing would be business, banking is definitely next in line. And I remember when I proposed to be a teacher [long silence]. My mother was horrified.

There is a point of similarity here between Anya and, Heena and Mariam's experiences. Anya's experience shows how, even in middle-class families, parents give priority to the material outcome of education (like Heena) but which contributes to sustaining an already high social status (like Mariam). Anya completed her studies reluctantly since she did not have parental support in studying for her personal fulfilment. This type of parental involvement acted both as tangible (e.g., parental investment) and intangible identity capital (e.g., development and acquisition of new resources). The former created opportunities to "access and benefit structural networks and positions" during the university-towork transition and eventually, for successful management of employment spaces (Côté, 2002, p. 120). 
The similarities and differences in Heena, Mariam and Anya's academic-related choices precisely illustrate Anthias's (2008) argument regarding the contextualised dimension of social divisions and how they may shift over time and space. Indeed, the selection of the university attended was grounded in the intersection of ethnicity and gender rather than social class since both middle-class and working-class participants shared a similar route into $\mathrm{HE}$ by opting for a local institution. Yet, once at university, which brought structural and individual changes, this dynamic shifted. The rationale for pursuing a degree was grounded in the women's social class, instead of their gender or ethnicity. These examples suggest how situational aspects allow privileging the intersection of certain identity categories contextually (such as gender and ethnicity over social class in choice of university) rather than "in any essential or given way" (Anthias, 2009, p. 12). In turn, these situational aspects enabled the women to draw on their identity capital in a diversified way in pursuit of success at university (even when completing their studies reluctantly).

\subsection{Strategies and Challenges in Building Successful Long-Term Careers}

\subsubsection{Waiting for a Graduate Job? The Impact of Social Class on Labour Market Transition}

Except Noreen (Pakistani, 35, middle-class) who found a position as surgical pharmacist immediately after graduation and Anya (Pakistani, 45, middle-class) who worked in her father's fast-food restaurant as manager, all the other participants experienced a period of unemployment. The longest unemployment period was 8 months (Leila, 26, Algerian, middle-class) and the shortest was 2 months (Raheela, 28, Pakistani, working-class). This was due to various factors, for instance, the women who gained their degrees shortly before/after 2008, suffered from the economic recession following the 2008 banking crisis as it made competition stiffer for them, especially for those who graduated in an oversubscribed field (e.g., business and administration) like Heena (Algerian, 23, working-class; HESA, 2009). When making sense of her four-month long unemployment, Heena, like the other new graduates, also attributed her failure to secure a job to a lack of added-value on her CV:

When you go for job interviews, they mainly ask about your experience and your experience will determine whether you get the job or not. You can have a firstclass degree...but if you don't have the experience then someone with the experience is more likely to get the job.

Brown and Hesketh (2004) argue that adding value to their CV is deemed indispensable for new graduates as degrees alone are no longer sufficient in an increasingly competitive market. Added value is not defined as rele- vant work experience, as many women described, but as something more tangible such as extra skills gained through charity work or a gap year that would increase the profitability of social capital (Bourdieu, 1980).

Accordingly, initial failure to secure suitable rolesmatching education level and field-pushed many women to accept precarious positions but which they believed would enhance their long-term employability. For example, Malika (Algerian, 26, working-class) who gained an MSc in Psychology was unemployed for five months. She then decided to work as a part-time retail assistant because the role offered flexibility and some financial independence. This decision enabled her to secure an unpaid assistant psychologist researcher position to gain much-needed work experience. Like Malika, the other women's lack of success in their initial attempts to find suitable jobs led them to take on non-relevant paid jobs and at the same time, pursue unpaid relevant roles. They believed that this strategy would add value to their CV and eventually, improve their chances of being employed in a relevant paid position.

Although this type of university-to-work transition (e.g., work on precarious contracts in unrelated fields at first) is in line with graduates' experiences in general (Moreau \& Leathwood, 2006), initial disadvantages remain significant, since the ability to add value to one's CV is highly affected by social class and ethnic factors. For example, many working-class women did not have the "luxury to wait or to pick and choose", as Sehrish (Pakistani, 42 , working-class) described, for the right opportunity to come along, to be in unpaid roles or to remain unemployed for an extended period of time. Sehrish, who graduated with an MA in Media and Communication, took on the role of a job centre advisor because she needed to support her family. Middle-class participants also compromised with their transition into employment but differently to their working-class counterparts.

For instance, Leila (Algeria, 26, middle-class) started off as an administrator, a role for which she was overqualified even though within her field. Nevertheless, she was promoted to a management position within a few months, a role equivalent to her academic qualifications. This strategy, being overqualified and underpaid in a relevant field, was made possible thanks to Leila's privileged class position. She was able to build her career by drawing on her parents' capital (here material capital, in comparison to Sehrish) and remained unemployed for eight months until the 'right job' came along. Thus, although both working- and middle-class parents' ethnic capital had a similar impact during the women's education (e.g., attendance of local institution), within the context of their university-to-work transition, the profitability of parent's capital, here material, differed (Anthias, 2008). Less-advantaged women were more likely to take a job, regardless of its status or employment conditions, compared to their more privileged peers, since they could not rely on their parents' material and ethnic capitals. In that respect, similarity in social class produced similarity 
in the women's decision-making process regarding their university-to-work transition.

\subsubsection{Tackling Racial Discrimination: The Impact of Ethnicity on Entry into the Labour Market}

In addition to managing initial personal disadvantages, the women also faced structural barriers. However, these barriers were perceived differently across groups. Although existing research shows the association between minority ethnicity and restricted labour market opportunities (e.g., Martin, Heath, \& Bosveld, 2010), no British Pakistani participant speculated about the existence of racism in the hiring process despite repeated and long-term job rejections ("I've never thought anything like that: 'your [last] name is Muhammad, it makes a difference [in job applications]'", Raheela, Pakistani, working-class). The reluctance of the British Pakistani women to recognise the existence of racism in the labour market was due to their strong belief in equal opportunity discourses and the comparison they drew between theirs and their parents' experiences stating that earlier generations (i.e., migrants from former colonies who arrived during the post-World War II migration wave) had to deal with racial discrimination but since then, legislation has been put in place to prevent any similar occurrences.

By contrast, British Algerian women discussed the existence of racism and how it impacts different spheres of life. For instance, six months into her period of unemployment, Leila (Algerian, middle-class) conducted a field experiment. Scholarly, this is known to reveal the extent of racial discrimination in the hiring process, where minority ethnic candidates are less likely to be called for an interview compared to White candidates (e.g., Wood, Hales, Purdon, Sejersen, \& Hayllar, 2009). This discrimination produces differences between minority and majority ethnic candidates in respect to their unemployment, earnings and occupational attainment (Heath \& Cheung, 2006):

I sent my CV to a job, hmm, and just changed the name. And, hmm, I was Sarah Adam [chuckled], who doesn't exist but got a call back for an interview. But the same CV with the same experience on it but with Leila Ibadi, the neutral sounding name got a call back for interview and the Muslim sounding name got rejected.... sent first with my name and got a rejection letter. And then sent the Sarah Adam's one and got a call to come in for an interview....And that kinda really depressed me for a really, really long time.... was really, really angry that I got a call back in, just a case of changing my name.

Anthias (2001, p. 847) argues that "a marketable skill [depends] on who possesses the skill" and who you deal with. In that respect, Leila's application, which demonstrated possession of the required skills (for at least to be considered for an interview), was rejected due to her name. Her ability "to fulfil the requirement of specific jobs" was weighed against her perceived religious identity and stereotypes associated with Muslim women (Brown \& Hesketh, 2004, p. 24). Her professional identity was challenged since certain characteristics, such as working as professionals, are attributed to White groups only (Weedon, 2004). In other words, Leila's application was rejected because she may have been positioned as an 'illegitimate' candidate who cannot claim her right to a graduate-level professional job (Goldberg, 2009). Leila's experience illustrates the complexity of the processes of identification of the minority ethnic graduates in this study, how they dealt with both personal (e.g., social class, degree gained) and structural factors (e.g., racial discrimination) and how these were managed both similarly and differently across and within groups during their university-to-work transition.

\subsubsection{Transforming Precarious Starts into Successful Long-Term Economic Positions}

Comparisons between the new graduates (with less than 5 years' experience post-graduation) and wellestablished women (over ten years' experience with the oldest participant, Anya, having accumulated 22 years) revealed strategies deployed by the latter in order to transform initial precarious professional positions into long-term economic stability and success. However, this remains true for the Pakistani women only due to their longer migration history. These women's employment trajectories showed a common pattern: they initially took on voluntary, fixed-term and/or part-time contracts in a relevant field and eventually saw their status changed. For example, Sehrish (Pakistani, 42, workingclass), who started on a fixed-term civil servant position (after the job centre position) moved to a permanent role following the end of her contract. She was able to create new social connections, and, as Bourdieu (1980) suggests, was able to take advantage of her expanded social capital. Indeed, when she decided to change careers, Sehrish was recommended by a previous work colleague for her current role as an executive director of a charity. These experiences were similar to the other well-established women suggesting that in many aspects, the women's identity capital was/is subject to shift and change with time.

Some women also decided to change careers for their personal fulfilment by creating a new negotiationresistance nexus with their parents. For example, Anya (Pakistani, 45, middle-class) who wished to become a teacher, returned to $\mathrm{HE}$ after having worked 5 years as a manager in her father's fast-food establishment. After successfully completing her initial teacher training, she moved up the employment ladder starting as an English supply teacher and achieving the position of Deputy Head (her current role). In line with the findings of previous studies (e.g., Dale et al., 2002), having gained an 
initial status in her family thanks to the empowerment conferred by her first job (as manager), she was able to negotiate her career progression with her parents and, after initial disapproval, they finally "recognised what a valuable career [teaching] is".

Returning to education was also used as a strategy to seek promotion. For example, Noreen (Pakistani, 35, middle-class) who started working as a surgical pharmacist enrolled for doctoral studies in order to become a clinical lecturer after 6 years of practice. By the time the participants took part in the second interview (approximately one year after the first), several new graduates also discussed having enrolled in or contemplating enrolling in additional (postgraduate) qualifications. For example, Malika (Algerian, 26, working-class) was finishing an application for her doctoral studies funded by the employer for whom she worked as an assistant psychologist researcher in a voluntary capacity. In that respect, returning to $\mathrm{HE}$ was seen by the new graduates as an additional strategy to add value to their CV, increase their identity capital and thus, enhance their employability in their preferred field.

Similar to the women's academic-related decisions, these work-related strategies, yet again, illuminate the situational reading of how social divisions operate dynamically over time and space (Anthias, 2008). Upon transition into the labour market, social class and ethnicity remained significant in shaping the women's decisions but in different contexts. The women in more privileged positions were able to wait longer for their preferred role, while their working-class counterparts had to compromise to secure a financial position as soon as possible. Ethnicity, however, became prominent in creating structural barriers in finding employment which captures the relational construction of ethnic categories in post-colonial societies. The examination of the women's careers further highlights the existence of shifting, transformative and contextual social categories since an empowered gender and ethnic position (partly afforded by a change in class position) altered the parent-daughter dynamic and subsequently, the women's professional pathway over the life course.

\section{Conclusions}

This article discusses the university-to-work transition and long-term economic positions of second-generation Pakistani and Algerian female graduates. It does so by highlighting both similarities and differences across the groups which helped consider the impact of personal and structural barriers over their life course. Theoretically, it brings forth the dynamic and contextualised interplay between the women's gender, social class and ethnicity (as a proxy for culture and religion) and, the specific use of their identity capital which shaped their choice of university, entrance in $\mathrm{HE}$, degree choice and level and, subsequent professional positions. In doing so, this article underlines the uniqueness of the women's experiences which lies in the ways in which their social class, gender and ethnic positions and identity capital (i.e., material, social, cultural and ethnic) shifted over time enabling them to navigate first their academic and then their professional pathways (Anthias, 2008). This article thus offers an intersectional reading of universityto-work transition and progress once in employment in three ways which moves beyond class-based or ethnic perspectives only.

First, for both groups, ethnicity was a major factor in the deployment of their ethnic and cultural capitals when selecting the university but the experience of going through $\mathrm{HE}$ differed across groups. In retrospect, Algerian participants shared satisfactory feelings for obtaining a university qualification, despite initial parental pressure, since it opened doors to professional roles and financial independence. Pakistani participants, instead, remained very negative while recalling similar experiences. This difference in how the women valued having a degree could be explained by the difference in the groups' migratory patterns and experiences. With a history of colonisation and the continuous existence of racism and discrimination in British society, Pakistani participants emphasised their right to equality in all spheres of lives. They shared a stronger sense of entitlement to professional roles (regardless of their CV) whereas Algerian participants expressed gratitude towards the UK for 'allowing' them to go to university and for accessing professional positions. This feeling among Pakistani participants was particularly intense considering these women's experiences of racism in the workplace (for a detailed discussion see, Naseem, 2017). In other words, degree or no degree, the women believed that they should have access to the labour market in a similar way to their White peers and should not "have to work twice as hard" (Sehrish, Pakistani, 42, working-class). In that sense, the ethnic comparison suggests that the interplay between migratory history and one's perception in British society may influence one's engagement within the educational system.

In other university-related decisions, the women's social class was more prominent than their ethnicity, especially in relation to their parents' input. Getting a university degree, for example, was valued by both Algerian and Pakistani parents (as reported by the participants) but the rationale for obtaining a degree differed. Although all women experienced strong parental involvement, for middle-class parents, getting a degree ensured maintenance of the family's prestige; while for working-class parents, the notion of pride was more significant. Accordingly, the women experienced a similar negotiation and resistance dynamic with their parents which positioned them as one and the same in this specific context.

Second, to a certain extent, upon transition into the labour market, the issues British Pakistani and Algerian women in this study faced mirrored those of any recently graduated individual. For instance, attending a post-92 
university may disadvantage candidates in favour of those who graduate from elite institutions (e.g., Noden et al., 2014). Similarly, potential employers' preference for candidates with relevant work experience prior to graduation can create stiffer competition for those without such credentials (e.g., Brown \& Hesketh, 2004). At the same time, these initial barriers can be overcome, for example, by the completion of further studies or, as discussed, by accepting roles 'below' the level of qualification. Indeed, difficulties in securing suitable jobs compelled many women, especially those from workingclass backgrounds who were unable to rely on their parents' material and ethnic capitals, to take on precarious employment, which often required lower qualifications, were unpaid and/or fixed-term positions. In that sense, despite being in employment, the minority ethnic graduates experienced inequalities which exist in forms beyond traditional understandings of economic segregation, gaps in earnings and differential professional progress (as is defined in existing research). Being in employment does not necessarily warrant professional success.

Precarious starts in relevant fields, however, enabled some women to increase their identity capital by expanding their social network and adding value to their CV. In addition, perseverance and ability to re-assess initial career and degree choices suggest possibilities to gradually move into stable employment positions and to build successful long-term careers. With time, the achievements of the well-established women may reflect in the progression of the new graduates in this study who discussed similar strategies to them, suggesting that precarious starts as new graduates may be temporary only.

The comparison between Algerian and Pakistani women further suggests how being absent from the social imaginary of the majority ethnic group becomes irrelevant in face of common structural barriers (here, religious discrimination), thus producing similar inequalities. Thus, compared to other new graduates, the women's university-to-work transition remained particular since their minority ethnicity became prominent in the assessment of their fit for a given role.

Finally, unlike other groups, including minority ethnic men, the dynamic of the parent-daughter relationship remained important beyond the women's education but differently. Their ability to negotiate with their parents was relevant in changing the course of their professional lives since university qualification and subsequent first employment enhanced their identity capital (notably material and social). Their new position (as a professional and university-educated woman) empowered them and, for some, placed them in a stronger position vis-à-vis their parents. This was especially important for the Pakistani and Algerian women who experienced the 'burden' of gender-specific cultural and religious expectations and/or those who lacked individual profitable identity capital compelling them to comply with their parents' decisions. This shift in the women's identity capital therefore highlights the fluidity of how gender and ethnicity operate in a situated and relational way (Anthias, 2008). In turn, the Pakistani and Algerian women's educational and employment experiences, overall, suggest that shifts in one's identity capital can change one's employability (positively) over the life course.

\section{Acknowledgments}

The author thanks all the women who participated in the study and the anonymous reviewers for their constructive criticism of the manuscript.

\section{Conflict of Interests}

The author declares no conflict of interests.

\section{References}

Afshar, H. (1989). Gender roles and the 'moral economy of kin' among Pakistani women in West Yorkshire. Journal of Ethnic and Migration Studies, 15(2), 211-225.

Afshar, H. (2008). Can I see your hair? Ethnic and Racial Studies, 31(2), 411-427.

Anthias, F. (2001). The concept of 'social divisions' and theorising social stratification. Sociology, 35(4), 835-854.

Anthias, F. (2008). Thinking through the lens of translocational positionality. Translocations, 4(1), 5-20.

Anthias, F. (2009). Translocational belonging, identity and generation. Finnish Journal of Ethnicity and Migration, 4(1), 6-15.

Archer, L., \& Francis, B. (2007). Understanding minority ethnic achievement, race, gender, class and 'success'. Abingdon: Routledge.

Bourdieu, P. (1980). Le capital social [Social capital]. Actes de la Recherche en Sciences Sociales, 31(1), 2-3.

Brah, A. (1996). Cartographies of diaspora. London: Routledge.

Brah, A. (2003). 'Race' and 'culture' in the gendering of labour markets. In H. Afshar \& M. Maynard (Eds.), The dynamics of 'race' and gender (pp. 151-171). Abingdon: Taylor \& Francis e-Library.

Brown, P., \& Hesketh, A. (2004). The mismanagement of talent. Oxford: Oxford University Press.

Collyer, M. (2003). Explaining change in established migration systems (Working Paper 16). Sussex: Sussex Centre for Migration Research. Retrieved from http://www.sussex.ac.uk/migration/research/ publications/workingpapers/wplist

Côté, J. (1996). Sociological perspectives on identity formation. Journal of Adolescence, 19(5), 417-428.

Côté, J. (2002). The role of identity capital in the transition to adulthood. Journal of Youth Studies, 5(2), 117-134.

Dale, A., Shaheen, N., Kalra, V., \& Fieldhouse, E. (2002). 
Routes into education and employment for young Pakistani and Bangladeshi women in the UK. Ethnic and Racial Studies, 25(6), 942-968.

Dwyer, C., \& Shah, B. (2009). Rethinking the identities of young British Pakistani Muslim women. In P. Hopkins \& R. Gale (Eds.), Muslims in Britain. Edinburgh: Edinburgh University Press.

Engzell, P. (2018). Aspiration squeeze. Sociology of Education, 92(1), 83-103.

Goldberg, D. (2009). Racial knowledge. In L. Back \& J. Solomos (Eds.), Theories of race and racism (pp. 226-252). Abingdon: Routledge.

Hantrais, L. (2009). International comparative research: Theory, methods and practice. Basingstoke: Palgrave Macmillan.

Heath, A., \& Cheung, S. Y. (2006). Ethnic penalties in the labour market: Employers and discrimination. Department for Work and Pensions.

Heath, A., Rothon, C., \& Kilpi, E. (2008). The secondgeneration in Western Europe. Annual Review of Sociology, 34, 211-235.

Higher Education Statistics Agency. (2009). Destination of 2004 school leavers. HESA. Retrieved from https://www.hesa.ac.uk/data-and-analysis/ publications/destinations-2004-05/introduction

Higher Education Statistics Agency. (2019). Higher education student statistics: UK 2017/18. Student numbers and characteristics. HESA. Retrieved from https://www.hesa.ac.uk/news/17-01-2019/sb252higher-education-student-statistics/numbers

Hussain, Y., \& Bagguley, P. (2012). Funny looks. Ethnic and Racial Studies, 36(1), 28-46.

ljaz, A., \& Abbas, T. (2010). The impact of intergenerational change on the attitudes of working-class South Asian Muslim parents on the education of their daughters. Gender and Education, 22(3), 306-322.

Jackson, M., Jonsson, J. O., \& Rudolphi, F. (2012). Ethnic inequality in choice-driven education systems. Sociology of Education, 85(2), 158-178.

Judt, T. (2007). Postwar. London: Pimlico.

Kamenou, N., Netto, G., \& Fearfull, A. (2013). Ethnic minority women in the Scottish labour market. British Journal of Management, 24(3), 398-413.

Khattab, N. (2009). Ethno-religious background as a determinant of educational and occupational attainment in Britain. Sociology, 43(2), 304-322.

Khattab, N. (2012). 'Winners' and 'losers'. Work, Employment \& Society, 26(4), 556-573.

Lessard-Philips, L., \& Li, Y. (2017). Social stratification of education by ethnic minority groups over generations in the UK. Social Inclusion, 5(1), 45-54.

Loury, G. C., Modood, T., \& Teles, S. M. (2005). Ethnicity, social mobility, and public policy comparing the USA and UK. Cambridge: Cambridge University Press.

Migration Policy Centre (2013). Algeria. Migration Policy Centre. Retrieved from http://www. migrationpolicycentre.eu/publications/migrationprofiles-fact-sheets

Malik, A., \& Wykes, E. (2018). British Muslims in UK higher education. London: The Bridge Institute. Retrieved from http://bridgeinstitute.co.uk/wpcontent/uploads/2018/10/Bridge-Higher-Educationreport-1-FINAL.pdf

Martin, J., Heath, A., \& Bosveld, K. (2010). Is ethnicity or religion more important in explaining inequalities in the labour market? (Working Paper 2010-02). Oxford: Oxford University, Department of Sociology. Retrieved from https://www.sociology.ox. ac.uk/materials/papers/2010-02.pdf

Modood, T. (2004). Capitals, ethnic identity and educational qualifications. Cultural Trends, 13(2), 87-105.

Modood, T., \& Calhoun, C. (2015). Religion in Britain: Challenges for higher education. London: Leadership Foundation for Higher Education. Retrieved from http://www.tariqmodood.com/uploads/1/2/ 3/9/12392325/6379_Ifhe_stimulus_paper__modood_calhoun_32pp.pdf

Moreau, M.-P., \& Leathwood, C. (2006). Graduates' employment and the discourse of employability. Journal of Education and Work, 19(4), 305-324.

Naseem, J. (2017). Capped equality in multicultural Britain: Experiences of everyday racism in the workplace among British Pakistani and Algerian women. Alizés, 42(November), 89-106.

Noden, P., Shiner, M., \& Modood, T. (2014). Black and minority ethnic access to higher education. London: LSE.

Office for National Statistics. (2016). 2011 census Data. ONS. Retrieved from https://discover.ukdataservice. ac.uk/doi/2011-census-aggregate

Organisation for Economic Co-operation and Development. (2018). Education at a Glance. OECD. Retrieved from https://read.oecd-ilibrary.org/education/ education-at-a-glance-2018_eag-2018-en\#page13

Rattansi, A. (2007). Racism. Oxford: Oxford University Press.

Rattansi, A. (2011). Multiculturalism. Oxford: Oxford University Press.

Reay, D., Crozier, G., \& Clayton, J. (2009). 'Fitting in' or 'standing out'. British Educational Research Journal, 36(1), 1-18.

Rose, D., \& Harrison, E. (2007). The European socioeconomic classification. European Societies, 9(3), 459-490.

The Change Institute. (2009). The Algerian Muslim community in England. The National Archives. Retrieved from https://webarchive.nationalarchives.gov.uk/ 20120920001108/http://www.communities.gov.uk/ documents/communities/pdf/1202966.pdf

Weedon, C. (2004). Identity and Culture. Oxford: Oxford University Press.

Wood, M., Hales, H., Purdon, S., Sejersen, T., \& Hayllar, O. (2009). A test for racial discrimination in recruitment practice in British cities (Research Report 607). London: NATCEN. Retrieved from http://natcen. ac.uk/our-research/research/a-test-for-racialdiscrimination-in-recruitment-practice-in-britishcities 


\section{About the Author}

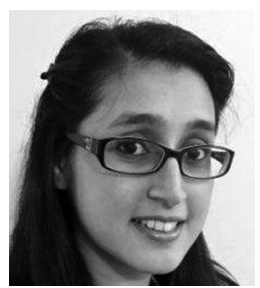

Jawiria Naseem is a Lecturer in Education and Social Justice at the University of Birmingham. Her main research interests lie in cross-country comparative research examining the dynamics of higher education and the labour market, and in understanding how intersecting identity positions shape life experiences and outcomes. 